\title{
Hepatoblastoma and APC gene mutation in familial adenomatous polyposis
}

F M Giardiello, G M Petersen, J D Brensinger, M C Luce, M C Cayouette, J Bacon, S V Booker, S R Hamilton

\begin{abstract}
Background-Hepatoblastoma is a rare, rapidly progressive, usually fatal childhood malignancy, which if confined to the liver can be cured by radical surgical resection. An association between hepatoblastoma and familial adenomatous polyposis (FAP), which is due to germline mutation of the APC (adenomatous polyposis coli) gene, has been confirmed, but correlation with site of APC mutation has not been studied.
\end{abstract}

Aim-To analyse the APC mutational spectrum in FAP families with hepatoblastoma as a possible basis to select kindreds for surveillance.

Patients-Eight patients with hepatoblastoma in seven FAP kindreds were compared with 97 families with identified APC gene mutation in a large Registry.

Methods-APC gene mutation was evaluated by RNase protection assay or in vitro synthesis protein assay. The $\chi^{2}$ test and correlation were used for data analysis.

Results-APC gene mutation was identified in all seven FAP kindreds in which an at risk member developed hepatoblastoma. A male predominance was noted (six of eight), similar to literature cases (18 of $25, p<0.01$. Mutations were restricted to codons 141 to 1230 , but no significant difference in site of mutation between pedigrees with and without hepatoblastoma was identified.

Conclusions-Hepatoblastoma occurs primarily in boys in FAP kindreds and is associated with germline APC mutation in the $5^{\prime}$ end of the gene. However, the site of APC mutation cannot be used to predict occurrence of this extracolonic cancer in FAP pedigrees.

(Gut 1996; 39: 867-869)

Keywords: familial adenomatous polyposis, adenomatous polyposis, hepatoblastoma, surveillance.

Familial adenomatous polyposis (FAP) is an autosomal dominant disorder characterised by the development during adolescence and young adulthood of hundreds to thousands of colorectal adenomas. ${ }^{1}$ If prophylactic colectomy is not performed, virtually all affected subjects will develop colorectal cancer by the fifth decade of life. FAP can be associated with extraintestinal lesions ('Gardner syndrome') such as soft tissue and bony tumours; desmoid tumours; and extracolonic cancers of the thyroid, duodenum, pancreas, liver, and brain. ${ }^{1-4}$

Hepatoblastoma is a rare malignant embryonal tumour of the liver, which occurs in infancy and childhood. An association between hepatoblastoma and familial adenomatous polyposis was first described by Kingston et al in $1982,{ }^{6}$ and since then over 30 additional cases have been reported. ${ }^{7-15}$ Moreover, a pronounced increased relative risk of hepatoblastoma in patients affected with FAP and their first degree relatives has been found (relative risk $847,95 \%$ confidence limits 230 and 2168)..$^{16}$

FAP is caused by germline mutations of the APC (adenomatous polyposis coli) gene located on the long arm of chromosome 5 in band q21. ${ }^{17-20}$ The APC gene has 15 exons and encodes a predicted gene product of 2843 amino acids with a molecular weight of about 300000 Daltons. Mutations of the APC gene have been reported in over 170 FAP patients. ${ }^{17}$ 19-32 Mutations are located primarily in the $5^{\prime}$ half but extend throughout the length of the APC gene, and most lead to truncation of the APC gene product.

The correlation of extracolonic phenotype with specific APC mutations has not been evaluated in detail. Two studies have suggested that the occurrence of pigmented ocular fundic lesions (congenital hypertrophy of the retinal pigmented epithelium) is restricted to APC mutation in codons 463 to $1387 . .^{33} 34$ One investigation found that patients with mutations between codons 1445 and 1578 frequently developed desmoid tumours. ${ }^{34}$ Also, Lynch et al described a cancer prone kindred with multiple members who had fewer than 100 flat appearing adenomas, which were located mainly in the right colon. ${ }^{35}$ After molecular examination of this kindred and six additional similar families ${ }^{36-38}$ demonstrated mutation in the very $5^{\prime}$ region of the APC gene, this variant of FAP was termed attenuated adenomatous polyposis coli by Spirio et al in $1992 .{ }^{39}$

Whether there is an association between APC gene mutation and development of hepatoblastoma has not been confirmed. Identification of specific mutations conferring susceptibility to hepatoblastoma could serve as the basis for surveillance directed at kindreds with these mutations. Therefore, we evaluated the site of APC gene mutation in seven familial adenomatous polyposis kindreds, which included eight patients with hepatoblastoma. 


\section{Methods}

Data were collected from The Johns Hopkins Polyposis Registry, which contains 382 pedigrees with familial adenomatous polyposis. Patient information was obtained on all registry subjects through chart review and was subsequently computerised. The diagnosis of hepatoblastoma in the study population was verified by review of the original pathology slides $(n=7)$ or report if the original slides were not available $(n=1)$. Seven of the cases were reported in our previous publication. ${ }^{7}$

Genotyping was done from peripheral blood leucocytes in one affected member with FAP from each family after informed consent was obtained. In five families, genomic DNA was evaluated for germline mutations by RNase protection assay after polymerase chain reaction amplification and then sequenced. ${ }^{4041}$ In two families, the APC mutation was identified by in vitro synthesis protein assay, ${ }^{42}$ as described previously, and the site of mutation was estimated from the size of the truncated product.

The frequency of pedigrees with $(n=7)$ and without hepatoblastoma ( $n=97)$ in the Registry was compared with the site of mutations in the APC gene by $\chi^{2}$ analysis. Correlation of age and survival with site of APC mutation was examined by calculation of Spearman's rank correlation coefficients.

\section{Results}

The Table lists the patients with hepatoblastoma in our Registry. ${ }^{7}$ All patients had one parent with FAP and therefore were at $50 \%$ risk for the development of this autosomal dominant disorder. Six of eight patients were male and all were white, but there were no statistically significant differences in demographics between these patients and the Registry population. When all literature cases (24 males, nine females with hepatoblastoma) were compared with the Registry population, there was a statistically significant predominance of male patients $(p<0 \cdot 01)$. All patients in the current series were diagnosed with hepatoblastoma before 10 years of age. Three patients survived hepatic resection and manifested adenomatous polyposis of the large bowel at $8 \cdot 8,13 \cdot 6$, and $18 \cdot 0$ years of age. The other five patients died within the first seven years of life and had no clinical evidence of colorectal polyposis. The absence of adenomatous polyposis in these patients is

Site of APC gene mutation in families with hepatoblastoma

\begin{tabular}{lllllll}
\hline & $\begin{array}{l}\text { Age at diagnosis } \\
\text { of hepatoblastoma } \\
(y)\end{array}$ & Race & Sex & $\begin{array}{l}\text { Age at diagnosis } \\
\text { of polyposis } \\
(y)\end{array}$ & $\begin{array}{l}\text { Status/length } \\
\text { of survival } \\
(y)\end{array}$ & $\begin{array}{l}\text { APc gene } \\
\text { mutation } \\
\text { (codon) }\end{array}$ \\
\hline 1 & $0 \cdot 1$ & W & F & - & Dead (0) & 215 \\
2 & $0 \cdot 7$ & W & M & $13 \cdot 6$ & Alive (20.0) & 302 \\
$3^{\star}$ & $1 \cdot 4$ & W & F & $18 \cdot 0$ & Alive (20.6) & 1230 \\
$4^{\star}$ & $2 \cdot 5$ & W & M & - & Dead (2.8) & 1230 \\
5 & $3 \cdot 4$ & W & M & - & Dead (0) & 1061 \\
6 & $3 \cdot 8$ & W & M & - & Dead (0) & $141^{\dagger}$ \\
7 & $4 \cdot 6$ & W & M & - & Dead (1.5) & 541 \\
8 & $9 \cdot 9$ & M & Alive (0.5) & $1189^{\dagger}$ \\
\hline
\end{tabular}

$\star$ Patients 3 and 4 are siblings. The site of mutation was estimated from the size of the truncated protein product in the in vitro synthesis protein assay. expected because of their young ages; the average age of diagnosis of adenomas in at risk subjects is 15 years of age. ${ }^{1}$

Mutation of the APC gene was found in all seven kindreds with a member who had hepatoblastoma. The mutations were restricted to codons 141 to 1230 , and all resulted in a truncated APC protein. Although no family with hepatoblastoma had a mutation $3^{\prime}$ to codon 1230, there was no statistically significant increase in frequency of hepatoblastoma in registry pedigrees with mutations in codons 1 to 1230 (seven of 83) compared with families with mutations in codons 1231 to 2843 ( 0 of 21$) \quad(p=0 \cdot 34)$. No significant correlations between site of mutation and age at diagnosis of hepatoblastoma or length of survival after diagnosis were found.

\section{Discussion}

Hepatoblastoma is a rapidly progressive tumour that carries a grave prognosis when malignancy has spread beyond surgical resection. ${ }^{6}$ In contrast, if diagnosed early, this tumour is potentially curable with surgery, as occurred in two of our eight FAP patients who had longterm survival. Intensive screening of infants and children in FAP pedigrees with high risk for hepatoblastoma could be accomplished if it were possible to identify subjects on the basis of their APC mutation.

In our study, hepatoblastoma occurred primarily in male patients (six of eight), which is similar to the male predominance noted in literature cases (18 of 25). This predominance suggests that diagnostic attention to hepatomegaly on physical examination or abnormalities of liver chemistries deserve particular attention in boys in FAP families. Furthermore, APC mutations in our pedigrees with hepatoblastoma were restricted to codons 141 to 1230 . Characterisation of the spectrum of APC mutations in additional FAP families with hepatoblastoma is needed to determine if this restriction can serve as a basis for surveillance because, the distribution of mutations was not statistically different from the site of mutations in pedigrees without hepatoblastoma. The site of APC gene mutation did not correlate with the characteristics of the tumour such as age of development or patient survival. For example, one of the two siblings with the same mutation survived (case 3 ) while the other died (case 4). Further research is needed to identify any factors that indicate youngsters at high risk for hepatoblastoma so that intensive surveillance can be started.

The limited spectrum of mutations in our study is intriguing because of the implications for understanding the functional domains of the APC gene product. Attenuated colorectal manifestations and pigmented ocular fundus lesions have been associated with mutations in specific regions of the APC gene. ${ }^{33-39}$ Also, somatic mutation of the APC gene has been found in sporadic hepatoblastoma. ${ }^{43}$ If hepatoblastoma is in fact restricted to subjects with germline or somatic mutations in the $5^{\prime}$ region 
of the APC gene, or both, the characterisation of APC gene function in the liver will be of considerable interest.

Supported in part by The Clayton Fund and NIH grants CA62924 and CA53801 from the National Institutes of Health, Department of Health and Human Services.

We are indebted to Drs Kenneth W Kinzler and Bert Vogelstein for their contributions to analysis of the APC gene mutations and Ms Linda Welch for secretarial support.

1 Bussey HJR, Familial adenomatous polyposis coli. Family studies, histopathology, differential diagnosis, and results of treatment. Baltimore, Maryland: Johns Hopkins University Press, 1975

2 Boland CR, Itzkowitz SH, Kim YS. Colonic polyps and the gastrointestinal polyposis syndromes. In: Sleisenger $\mathrm{MH}$, Fordtran JS, eds. Gastrointestinal disease: pathophysiology, diagnosis and management. 4th ed. Philadelphia: WB dagnosis and management 1989: 1500-7.

3 Haggitt RC, Reid BJ. Hereditary gastrointestinal polyposis syndromes. Am $\mathcal{F}$ Surg Pathol 1986; 10: 871-87.

4 Hamilton SR, Liu B, Parsons RD, Papadopolous NC, Jen J, Powell S, et al. The molecular basis of Turcot syndrome. $N$ Engl f Med 1995; 332: 839-47.

5 Lack EE, Neave C, Vawter GF. Hepatoblastoma: a clinical and pathologic study of 54 cases. Am $\mathcal{F}$ Surg Pathol 1982, 6: 693-705.

6 Kingston JE, Draper GJ, Mann JR. Hepatoblastoma and polyposis coli. Lancet 1982; i: 457 .

7 Krush AJ, Traboulsi EI, Offerhaus GJA, Maumenee IH, Yardley JH, Levin LS. Hepatoblastoma, pigmented ocular fundus lesions and jaw lesions in Gardner syndrome. $\mathrm{Am}$ $7 \mathrm{Med}$ Genet 1988; 29: 323-32.

8 Kingston JE, Herbert A, Draper GJ, Mann JR. Association between hepatoblastoma and polyposis coli. Arch Dis Child 1983; 58: 959-62.

9 Kasukawa T, Watanabe T, Endo A. Cytogenetic and cytokinetic analysis of lymphocytes from patients with hereditary adenomatosis of the colon and rectum. Cancer Genet Cytogenet 1985; 16: 73-9.

$10 \mathrm{Li}$ FP, Thurber WA, Seddon J, Holmes GE. Hepatoblastoma in families with polyposis coli. $\mathscr{f} A M A 1987$ 257: 2475-7.

11 LeSher AR, Castronuovo JJ Jr, Filipone AL Jr. Hepatoblastoma in a patient with familial polyposis coli. Surgery 1989; 105: 668-70.

12 Phillips M, Dicks-Mireaux C, Kingston J, Malone $M$ Mitchell C, Pritchard J, et al. Hepatoblastoma and polyposis coli. Med Pediatr Oncol 1989; 17: 441-7.

13 Toyama WM, Wagner S. Hepatoblastoma with familia polyposis coli: another case and corrected pedigree. Surgery 1990; 108: 668-70.

14 Riikonen $P$, Tuominen L, Seppa A, Perkkio M Simultaneous hepatoblastoma in identical twins. Cancer 1990; 66: 2429-31.

15 Garber JE, Li FP, Kingston JE, Krush AJ, Strong LC Finegold MJ, et al. Hepatoblastoma and familial adenomatous polyposis. 7 Natl Cancer Inst 1988; 80: 1626-8.

16 Giardiello FM, Offerhaus GJA, Krush AJ, Booker SV, Tersmette AC, Mulder JR, et al. The risk of hepatoblastoma in familial adenomatous polyposis. $\mathscr{f}$ Pediatr 1991; 119: 766-8.

17 Nishisho I, Nakamura Y, Miyoshi Y, et al. Mutations of chromosome $5 \mathrm{q} 21$ gene in FAP and colorectal cancer patients. Science 1991; 253: 665-9.

18 Kinzler KW, Nilbert MC, Su LK, et al. Identification of FAP locus genes from chromosome 5q21. Science 1991; 253: 661-5.

19 Groden J, Thliveris A, Samowitz W, et al. Identification and characterization of the familial adenomatous polyposis coli gene. Cell 1991; 66: 589-600.

20 Joslyn G, Carlson M, Thliveris A, et al. Identification of deletion mutations and three new genes at the familial polyposis locus. Cell 1991; 66: 600-13.

21 Miyoshi $\mathrm{Y}$, Ando $\mathrm{H}$, Nagase $\mathrm{H}$, et al. Germ-line mutations of the APC gene in 53 familial adenomatous polyposis patients. Proc Natl Acad Sci 1992; 89: 4452-6.
22 Nagase H, Miyoshi Y, Horii A, et al. Correlation between the location of germ-line mutations in the APC gene and the number of colorectal polyps in familial adenomatous polyposis patients. Cancer Res 1992; 52: 4055-7.

23 Stella A, Lonoce A, Resta N, et al. Familial adenomatous polyposis - identification of a new frameshift mutation of the APC gene in an Italian family. Biochem Biophys Res Commun 1992; 184: 1357-63.

24 Cottrell S, Bicknell D, Kaklamanis L, Bodmer WF. Molecular analysis of APC mutations in familial adenomatous polyposis and sporadic colon carcinomas. Lancet 1992; 340: 629-9.

25 Fodde R, Vanderluijt R, Wijnen J, et al. Eight novel inactivating germ line mutations at the APC gene identified by denaturing gradient gel electrophoresis. Genomics 1992; 13: 1162-8.

26 Olschwang S, Laurent-Puig P, Groden J, White R, Thomas G. Germ-line mutations in the first 14 exons of the adenomatous polyposis coli (APC) gene. Am f Hum Genet 1993; 52: 273-9.

27 Paul P, Letteboer T, Coppes M. SSCP detection of APC gene mutations in familial adenomatous polyposis. $\mathrm{Am} \mathfrak{f}$ Hum Genet 1992; 51: A67.

28 Nagase $\mathrm{H}$, Miyoshi Y, Horii A, et al. Germ-line mutations of the APC gene in patients with familial adenomatous polyposis: screening of 150 unrelated patients. Am $\mathcal{F} \mathrm{Hum}$ polyposis: screening of

29 Wallis Y, MacDonald F, Rindl PM, et al. Germline APC mutation familial adenomatous polyposis in an Indian family. Lancet 1992; 340: 1035.

30 Vareso L, Gismondi V, James R, et al. Identification of APC gene mutations in Italian adenomatous polyposis coli patients by PCR-SSCP analysis. Am f Hum Genet 1993; 52: $280-5$.

31 Groden J, Gelbert L, Thliveris A, et al. Mutational analysis of patients with adenomatous polyposis: identical inactivating mutations in unrelated individuals. $A m f$ Hum Genet 1993; 52: 263-72.

32 Beroud C, Soussi T. APC gene: database of germline and somatic mutations in human tumors and cell lines. Nucl Acid Res 1996; 24: 121-4.

33 Olschwang S, Tiret A, Laurent-Puig P, Muleris M, Parc R, Thomas G. Restriction of ocular fundus lesions to a specific subgroup of APC mutations in adenomatous polyposis coli patients. Cell 1993; 75: 959-68.

34 Caspari R, Olschwang S, Friedi W, Mandl M, Boisson C, Boker T, et al. Familial adenomatous polyposis: desmoid tumors and lack of ophthalmic lesions (CHRPE) association with APC mutations beyond codon 1444 . Human Mol Genet 19955; 4: 337-40.

35 Lynch HT, Smyrk T, Lanspa SJ, Marcus JN, Kregler M, Lynch JF, et al. Flat adenomas in a colon cancer-prone kindred. $\mathcal{F}$ Natl Cancer Inst 1988; 80: 278-82

36 Lynch HT, Smyrk T, Lanspa SJ, Lynch PM, Watson P, Strayhorn PC, et al. Phenotypic variation in colorectal Strayhorn PC, et al. Phenotypic variation in colorectal adenoma syndrome. Cancer 1990; 66: 909-15.

37 Leppert M, Burt R, Hughes JP, Samowitz W, Nakamura Y, Woodward $S$, et al. Genetic analysis of an inherited predisposition to colon cancer in a family with a variable number of adenomatous polyps. $N$ Engl f Med 1990; 322: 904-8.

38 Spirio L, Olschwang S, Groden J, Robertson M, Samowitz W, Joslyn G, et al. Allelles of the APC gene: An attenuated form of familial polyposis. Cell 1993; 75: 951-7.

39 Spirio L, Otterud B, Stauffer D, Lynch H, Lynch P, Watson $\mathrm{P}$, et al. Linkage of a variant or attenuated form of adenomatous polyposis coli to the adenomatous polyposis coli (APC) locus. Am f Hum Genet 1992; 51: polyposis

40 Miyoshi Y, Ando $\mathrm{H}$, Nagase $\mathrm{H}$, et al. Germ-line mutations of the APC gene in 53 familial adenomatous polyposis of the APC gene in 53 familial adenomatou

41 Nagase H. Miyoshi Y, Horii A, al Germ-line mutations of the APC gene in patients with familial adenomatous polyposis: screening of 150 unrelated patients. $\mathrm{Am} \mathcal{F} \mathrm{Hum}$ Genet 1992; 51: A39.

42 Powell SM, Petersen GM, Krush AJ, Booker SV, Jen J, Giardiello FM, et al. Molecular diagnosis of familial adenomatous polyposis. $N$ Engl $f$ Med 1993; 329: 1982-7.

43 Kurahashi $H$, Takami K, Oue T, Kusafuka T, Okada A, Tawa A, et al. Biallelic inactivation of the APC gene in hepatoblastoma. Cancer Res 1995; 55: 5007-11. 